High stakes
Researchers launch
lawsuit to secure
legal marijuana
$p 492$

\title{
Lawyers blast nuclear pact as a breach of disarmament treaty
}

\section{Jim Giles, London}

The impending renewal of a pact on nuclear research between the United Kingdom and the United States could breach the Nuclear Non-Proliferation Treaty (NPT), British lawyers say.

Critics argue that the two countries have long been in violation of the NPT, the cornerstone of international attempts to halt the spread of nuclear arms, both in spirit and in the letter of the law. But this year's pending renewal of the US/UK Mutual Defence Agreement (MDA) prompted advocacy groups to seek a legal opinion on the matter. Armed with this advice, they are hoping to force both countries to take disarmament more seriously.

The MDA dates from 1958 and allows for the exchange of plans for the research and development of nuclear weapons between Britain and the United States. Such collaboration aided the development of Britain's nuclear weapon system, Trident, for example. But both countries have also signed the NPT, which came into force in 1970 and requires them to work towards disarmament.

Britain and the United States have improved their weapons systems since the NPT became binding, arguing that they have stuck to its spirit by working to reduce the overall number of nuclear arms. Disarm-

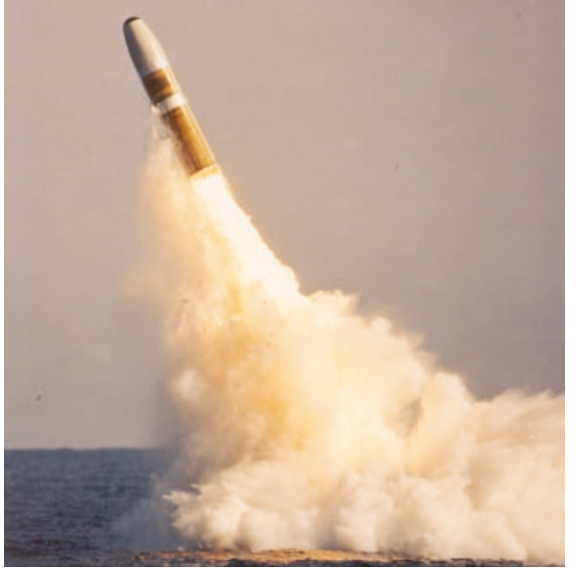

Collaboration between US and UK scientists helped develop the Trident nuclear missiles.

ament advocates counter that any work to improve weapons is a legal breach of the treaty.

It is a grey area, but lawyers have now tipped the balance in favour of those who criticize the MDA. "It is strongly arguable that the renewal of the MDA is in breach of the NPT," conclude Rabinger Singh and Christine Chinkin, lawyers at Matrix Chambers in London, who were hired by a number of UK-based advocacy groups.

Neither Britain nor the United States will discuss details of the research that goes on under the agreement. A spokesman for the UK Ministry of Defence points out that the allies regularly exchange information on how to safeguard existing nuclear weapons, rather than information about developing new ones. But researchers who took part in previous MDA collaborations, including Bob Peurifoy, former chief weapons designer at Sandia National Laboratories in Albuquerque, New Mexico, say that weapons development has definitely been part of discussions in the past. "The designs were better because of the exchange," Peurifoy says.

Britain has already declared its intention to renew the MDA for a further 10 years, and the agreement is expected to pass through US Congress without debate.

The British American Security Information Council, one of the advocacy groups that commissioned the Matrix lawyers, says that it is considering seeking a judicial review of the UK decision to renew the MDA - if it can come up with the money needed to do so.

Daryl Kimball, executive director of the Arms Control Association in Washington DC, says the lawyers' conclusion highlights the secrecy that surrounds the MDA. "The United States and the United Kingdom should be more transparent. If no there is no violation, they should provide more information," he says.

\section{Energy labs halt classified research amid security fears}

\section{Geoff Brumfiel, Washington}

The bulk of classified research at all 24 labs run by the US Department of Energy was shut down this week after officials decided that the security problems recently found at the Los Alamos National Laboratory in New Mexico might also exist elsewhere.

Several computer disks went missing at Los Alamos earlier this month, prompting energy secretary Spencer Abraham to halt all work at the lab until the problems are ironed out (see Nature 430, 387; 2004). As of $26 \mathrm{July,}$ two missing disks had still not been found, and 15 employees had been suspended in connection with the disappearance.

Now all energy labs will stop doing classified research that involves removable storage devices - such as computer disks until all the devices are accounted for and new procedures are in place for monitoring their handling by laboratory employees.

"While we have no evidence that the problems currently being investigated are present elsewhere, we have a responsibility to take all necessary action to prevent such problems," Abraham said on 23 July.

The shut-down isn't quite as dramatic as it sounds, experts say. Only two labs will be seriously affected: Sandia National Laboratories in Albuquerque, New Mexico, and Lawrence Livermore National Laboratory in California. Together with Los Alamos, these two labs conduct the bulk of the country's nuclear-weapons programmes. At Livermore, 876 employees will be suspended during the inventory of some 12,000 items of classified removable material.

At other labs, far fewer people will be affected. "The impact should be minimal," says Martha Krebs, former director of the energy department's science office. 